\title{
STRUCTURAL INVESTIGATIONS OF CANDIDATE MATERIALS FOR TURBINE DISC APPLICATIONS BEYOND $700^{\circ} \mathrm{C}$
}

\author{
H.J. Penkalla, J. Wosik, W. Fischer, F. Schubert \\ Research Center Jülich, Institute for Materials and Processes in Energy Systems \\ D-52425 Jülich, Germany
}

\begin{abstract}
Three Ni-base wrought alloys with different hardening mechanisms (Inconel 706, Waspaloy and Inconel 617) are candidates for steam turbine disc applications with temperatures up to $700{ }^{\circ} \mathrm{C}$ and were examined in respect to their microstructure and microstructural stability. The materials were investigated after different heat treatments and after short and long term ageing by metallography, scanning and transmission electron microscopy. Special DTA experiments has been performed to confirm the known TTT diagrams and to study the initial precipitation of different phases and their growth, as function of cooling rate after the heat treatment. The amount and size of precipitations were evaluated by image analysis and stereological methods.

The Nb containing alloy Inconel 706 shows a complex microstructure containing $\gamma^{\prime}, \gamma^{\prime \prime}$ and $\eta$ phases which are stable under long term service up to $620^{\circ} \mathrm{C}$. At higher temperatures a strong particle coarsening and phase transformation was observed. Waspaloy is hardened by $\gamma^{\prime}$ particles with a bimodal size distribution. After ageing at $700^{\circ} \mathrm{C}$ and higher a coarsening was observed by loss of the bimodal size distribution. Inconel 617 is a solid solution hardened material additionally hardened by homogeneously distributed fine $\mathrm{M}_{23} \mathrm{C}_{6}$ carbides. After long term ageing at temperatures of $650{ }^{\circ} \mathrm{C}$ to $750{ }^{\circ} \mathrm{C}$ the carbides tended to form carbide films along the grain boundaries and at $700^{\circ} \mathrm{C}$ to $750{ }^{\circ} \mathrm{C} \gamma$ precipitated to homogeneously distributed particles with low coarsening under long term service.
\end{abstract}

Superalloys $718,625,706$ and Various Derivatives

Edited by E.A. Loria

TMS (The Minerals. Metals \& Materials Society), 2001 


\section{Introduction}

An increase in the efficiency of steam power plants can be reached by increasing the steam temperature. In future, power plant for electricity generation will, for thermal efficiency and ecological reasons, operate with steam temperatures as high as $700^{\circ} \mathrm{C}$. The currently used martensitic/feritic steels are limited to application temperatures of about $620^{\circ} \mathrm{C}$ [1]. Many existing polycrystalline nickel-base superalloys, used in the aerospace aircraft turbine engines could be principal used for this high temperatures, but they are not fabricable to heavy components and too expensive to be used in power plant components. Ni-base wrought superalloys with good formability, sufficient creep strength and creep crack growth resistance and high structure stability during long term service at the application temperatures may be candidate material for large components.

Within the context of a German DFG research project "Production and life time models for the application of Ni-base alloys in steam turbines at temperatures above $700{ }^{\circ} \mathrm{C}$ " different aspects of the use of Ni-base superalloys should be modeled. In order to collect a data base for the modeling, in a first screening step three candidates, Inconel 706, Inconel 617 and Waspaloy, have been investigated in respect to their casting, forgeability, heat treatment, structure and structural stability and mechanical properties such as creep strength and creep crack growth behavior in the temperature range of 650 to $750{ }^{\circ} \mathrm{C}$.

An important criterion for these material selections was the differences in the hardening mechanisms of these alloys. Inconel 617 is representative for solid solution hardened Ni-base alloys, Waspaloy is hardened by coherent $\gamma$ 'particles and Inconel 706 shows a complex microstructure with $\gamma^{\prime}, \gamma^{\prime}$ ' and $\eta$ phase. In the following contribution the aspects of the alloy structure and the structural stability will be reported.

\section{Experiments}

\section{Materials and heat treatment}

Inconel 706 is a $\mathrm{Nb}$ containing Ni-Fe-base superalloy derived from Inconel 718 with higher Fe and $\mathrm{Ti}$ content to improve the forgeability and to reduce the tendency for segregation [2-5]. The microstructure consists of fine $\gamma^{\prime}$ and $\gamma^{\prime}$ precipitates, homogeneously distributed in the $\gamma$ matrix, and, depending on the heat treatment, $\eta$-phases along the grain boundaries as a cellular structure. Additionally $\mathrm{M}(\mathrm{C}, \mathrm{N})$ carbonitrides can be found. Inconel 617 is a solid solution hardened material and shows after heat treatment a distribution of small $\mathrm{M}_{23} \mathrm{C}_{6}$ precipitates in the matrix and along the grain boundaries. Waspaloy is hardened by $\gamma^{\prime}$ precipitates in a bimodal size distribution of primary and secondary particles and a small part of $\mathrm{M}_{23} \mathrm{C}_{6}$ particles, which tend to precipitate at the grain boundaries in a globular shape.

The chemical composition of the investigated alloys is shown in Table 1. From Inconel 706 three variants were investigated to observe the influence of the heat treatment and the $\mathrm{Nb}$ and $\mathrm{C}$ content on the amount and structure of precipitates. The variant Inconel $706 \mathrm{~A}$ and Inconel $706 \mathrm{~B}$ with the same nominal chemical composition obtained different heat treatments. Inconel $706 \mathrm{C}$ has higher $\mathrm{Nb}$ and $\mathrm{C}$ concentrations and was heat treated like Inconel $706 \mathrm{~B}$. 
Table 1: Nominal chemical composition of Inconel 706, Inconel 617 and WASPALOY

\begin{tabular}{|l|c|c|c|c|}
\hline \multicolumn{5}{|c|}{ Chemical composition wt\% } \\
\hline Element & Inconel 706A+B & Inconel 706 C & Inconel 617 & Waspaloy \\
\hline $\mathbf{N i}$ & 42 & 42.46 & 54 & 57.1 \\
\hline $\mathbf{F e}$ & 37.1 & 36.19 & 0.5 & 0.57 \\
\hline $\mathbf{C r}$ & 16 & 16.04 & 22 & 19.35 \\
\hline $\mathbf{T i}$ & 1.54 & 1.61 & 0.55 & 3.13 \\
\hline $\mathbf{A l}$ & 0.26 & 0.17 & 1.11 & 1.22 \\
\hline $\mathbf{N b}$ & 2.96 & 3.33 & 0 & 0.01 \\
\hline $\mathrm{C}$ & 0.01 & 0.05 & 0.55 & 0.033 \\
\hline $\mathrm{B}$ & 0.0034 & & 0.001 & 0.005 \\
\hline $\mathbf{C o}$ & & & 12.9 & 14 \\
\hline $\mathbf{M o}$ & & & 9.05 & 4.52 \\
\hline $\mathrm{Si}$ & 0.05 & & 0.14 & 0.04 \\
\hline
\end{tabular}

Inconel $706 \mathrm{~A}$ has been solution treated at $980^{\circ} \mathrm{C}$ for $2 \mathrm{~h}$ with a following cooling down to room temperature at a cooling rate of $25 \mathrm{~K} / \mathrm{min}$ (Figure 1). The subsequent precipitation annealing was performed at $720^{\circ} \mathrm{C}$ for $8 \mathrm{~h}$ and at $620^{\circ} \mathrm{C}$ for $8 \mathrm{~h}$. This heat treatment results in a homogeneous distribution of small $\gamma^{\prime}$ and $\gamma^{\prime}$ 'precipitates, the $\eta$ phase is absent.

In order to precipitate the $\eta$ phase the heat treatment of variant Inconel $706 \mathrm{~B}$ was used. This heat treatment according to the results of Shibata [5] introduces a stabilizing step at $820^{\circ} \mathrm{C}$ for $8 \mathrm{~h}$ following solution annealing. Different to the Shibata's heat treatment the stabilizing follows directly solution annealing by cooling down from $980^{\circ} \mathrm{C}$ to $820^{\circ} \mathrm{C}$ at a cooling rate of $4 \mathrm{~K} / \mathrm{min}$. This procedure should avoid initial $\gamma^{\prime}$ and $\gamma^{\prime}$ precipitation during the cooling down before $\eta$ phase precipitates.

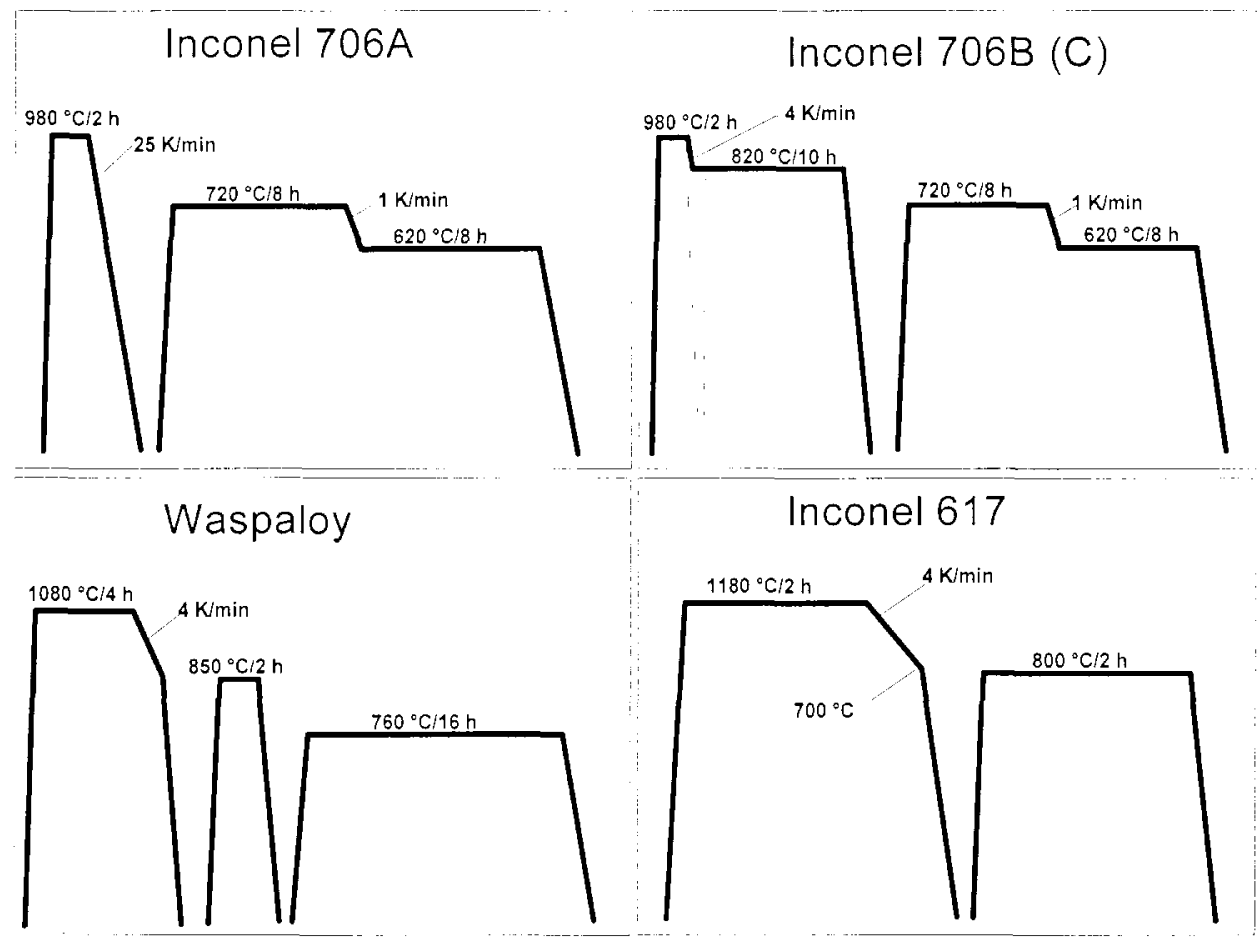

Figure 1: Heat treatments of the investigated alloys. The dashed lines indicate the heat treatment proposed by Shibata [5]. 
The heat treatment of Inconel 617 consist of two steps, an initial solution annealing at $1180^{\circ} \mathrm{C}$ for $2 \mathrm{~h}$ and a precipitation annealing at $800^{\circ} \mathrm{C}$ for $2 \mathrm{~h}$. After the solution annealing the specimen was cooled down to room temperature. Down to $700{ }^{\circ} \mathrm{C}$ the cooling rate was limited to $4 \mathrm{~K} / \mathrm{min}$ to avoid a supersaturation of $\mathrm{C}$ in the matrix. This procedure leads to a homogeneous distribution of $\mathrm{M}_{23} \mathrm{C}_{6}$ during the stabilizing annealing. The temperature of $800{ }^{\circ} \mathrm{C}$ was chosen to avoid an additional $\gamma$ ' precipitation, which may occur at heat exposure in the temperature range of $650^{\circ} \mathrm{C}$ to $750^{\circ} \mathrm{C}$.

Waspaloy alloy was solution treated at $1080^{\circ} \mathrm{C}$ for $4 \mathrm{~h}$, followed by ageing at $850{ }^{\circ} \mathrm{C}$ for $2 \mathrm{~h}$ and at $760{ }^{\circ} \mathrm{C}$ for $16 \mathrm{~h}$. Between the three annealing steps the specimen were cooled down to room temperature, particularly after the solution annealing up to $700{ }^{\circ} \mathrm{C}$ with a cooling rate of $4 \mathrm{~K} / \mathrm{min}$.

Table 2 shows the grain size and hardness HV 10 of the investigated materials. The $\gamma^{\prime}$ and $\gamma^{\prime \prime}$ hardened Inconel $706 \mathrm{~A}$ shows the highest value of hardness. The $\eta$ phase in the variants Inconel $706 \mathrm{~B}$ and Inconel $706 \mathrm{C}$ leads to a loss of hardness of about $10 \%$.

Table 2: Grain size and hardness of the investigated alloys

\begin{tabular}{|l|l|l|}
\hline Material & mean grain size $(\mu \mathrm{m})$ & hardness HV 10 \\
\hline Inconel 706 A & 39 & 426 \\
\hline Inconel 706 B & 69 & 378 \\
\hline Inconel 706 C & 130 & 376 \\
\hline Inconel 617 & 223 & 169 \\
\hline Waspaloy & 44 & 328 \\
\hline
\end{tabular}

\section{Methods of investigations}

The microstructural investigations were carried out using scanning and transmission electron microscopy (SEM, TEM). The preparation of thin foil specimens for TEM examinations were mechanically thinned to about $80 \mu \mathrm{m}$ thickness, followed by double jet polishing (Tenupol) to 5 $\mu \mathrm{m}$ residual thickness in the etching dimple. The last step of thinning was done by small-angle ion beam milling (Gatan PIPS) with angles of -3 , and $+4^{\circ}$ and an energy of $5 \mathrm{keV}$. The conditions of the clectrolytic polishing process were: temperature $-25^{\circ} \mathrm{C}$, voltage $22 \mathrm{~V}$, solution: 60 $\mathrm{ml}$ perchloric acid, $620 \mathrm{ml}$ ethanol, $310 \mathrm{ml}$ butyglycol. For TEM replicas, the specimens were thinned to about $40 \mu \mathrm{m}$ thickness and covered on both side with a thin carbon film. Then the matrix was dissolved in a solution of $10 \%$ bromium in ethanol. TEM investigation were carried out using a JEOL $200 \mathrm{CX}$ and Philips CM200 combined with a Gatan Image Filter (GIF); the SEM investigations were carried out using LEO1530/Gemini microscope.

Specimens for SEM investigation were prepared to a polished surfaces and etched with $10 \%$ phosphoric acid at a voltage $3 \mathrm{~V}$. The measurement of particle sizes and the evaluation of size distributions were carried out by the image analysis system KS400 from Kontron. The images were taken on the electron microscopes in digital format or, if the contrast was too low, redrawn from a printed copy and scanned from the image analysis system.

In order to observe the phase transition and to verify the TTT diagrams from the literature, some experiments were carried out in a DTA (differential thermal analysis) facility. Specimens of $6 \mathrm{~mm}$ diameter and $10 \mathrm{~mm}$ length were heated up to the solvus temperature and cooled down 
with different constant cooling rates. The temperature differences were measured against a standard specimen of $\mathrm{Pt}$.

\section{Results and discussion}

\section{Inconel 706A}

Microstructure after heat treatment. The variant Inconel $706 \mathrm{~A}$ after heat treatment exhibited two types of precipitation, the coherent $\gamma$ ' phase of $\mathrm{Ni}_{3}(\mathrm{Ti}, \mathrm{Al})$ and the metastable semicoherent $\gamma$ '" phase of $\mathrm{Ni}_{3}(\mathrm{Nb}, \mathrm{Ti})$. In Figures 2 and 3 TEM images of Inconel $706 \mathrm{~A}$ alloy are shown. The spherical precipitates observed inside the grains were identified as $\gamma^{\prime}$ phase and the disc shaped precipitates as $\gamma$ ' phase. The $\gamma$ ' and $\gamma$ ' particles were homogeneously distributed inside grains with volume fractions of about $3 \%$ for $\gamma$ ' and $4 \%$ for $\gamma$ '. The mean length of $\gamma$ ', particles was about $20 \mathrm{~nm}$ and the diameter of the spherical $\gamma^{\prime}$ particles about 10 to $15 \mathrm{~nm}$. Figure 3 shows the orientation of $\gamma$ " particles related to the matrix where the coherent planes of $\gamma$ ' are parallel to the $\langle 100>$ or $<010>$ planes of the matrix.

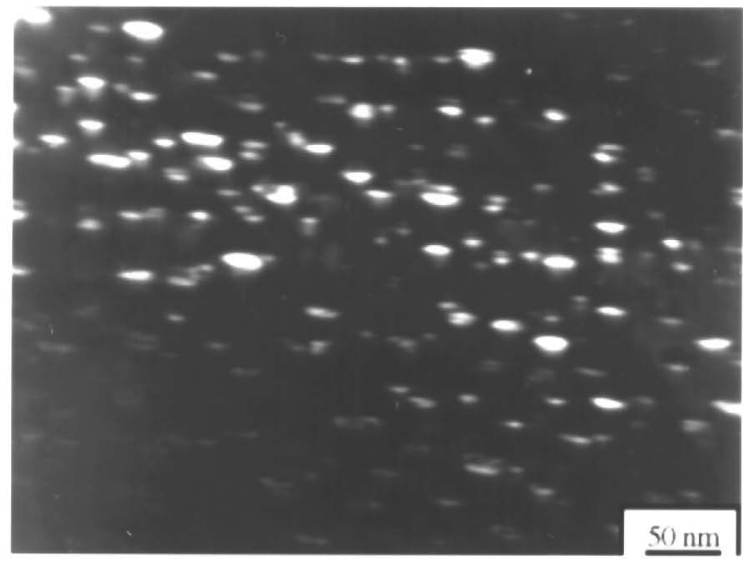

Figure 2: Homogeneously distributed $\gamma^{\prime}$ and $\gamma^{\prime \prime}$ particles in Inconel 706 A (TEM dark field)

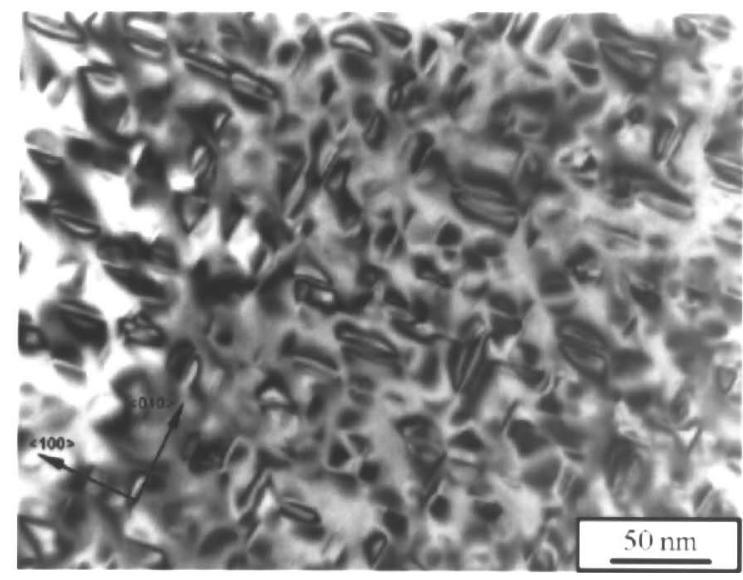

Figure 3: Coherence contrast of $\gamma$ " particles demonstrates the orientation to the $<100>$ and $<010\rangle$ directions in the matrix

Microstructure after ageing. To observe the structural changes in Inconel $706 \mathrm{~A}$ at elevated temperatures some ageing experiments were carried out at temperatures of $600,650,700$ and

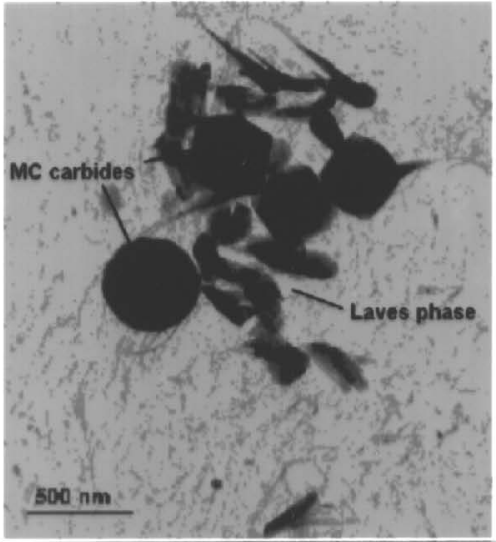

Figure 4: Laves plates in Inconel $706 \mathrm{~A}$ after $10000 \mathrm{~h}$ at $650^{\circ} \mathrm{C}$ (replica)

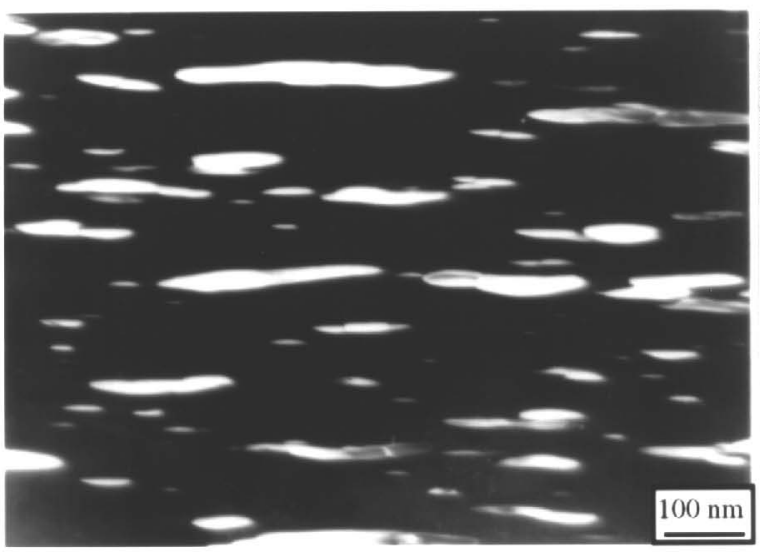

Figure 5: Microstructure of Inconel $706 \mathrm{~A}$ after ageing at $650^{\circ} \mathrm{C}$ and $30000 \mathrm{~h}$ (TEM dark field) 
$750^{\circ} \mathrm{C}$ with exposure times up to $30000 \mathrm{~h}$. At temperatures up to $620^{\circ} \mathrm{C}$ and exposure times up to $1000 \mathrm{~h}$ no significant changes of the $\gamma^{\prime}$ and $\gamma^{\prime}$ 'particle size was observed, but the Laves phase of the $\mathrm{Fe}_{2} \mathrm{Nb}$ type appeared at $600{ }^{\circ} \mathrm{C}$ after less than $3000 \mathrm{~h}$. It was found as clusters of small platelets near to $\mathrm{MC}$ carbides. Figure 4 demonstrates this fact by a TEM replica image, where the larger particles are MC carbides and the small plates or needles are the Laves phase.

At temperatures of $650^{\circ} \mathrm{C}$ and higher the $\gamma^{\prime \prime}$ particles grew significantly. The changes in particle size and morphology in Inconel $706 \mathrm{~A}$ after ageing at $650^{\circ} \mathrm{C}$ and $30000 \mathrm{~h}$ is presented in Figure 5. The main aspect of this image is the directional coarsening process of $\gamma^{\prime}$. The $\gamma^{\prime}$ platelets grew in defined $<001>$ direction of the matrix $(\gamma)$. This behavior can be explained by a minimization of coherency strain during the particle growth [6].

Table 3 and Figures 6 and 7 present the $\gamma$ " particle size distribution and aspect ratio for Inconel $706 \mathrm{~A}$ in dependence on the exposure time and temperature.

Table 3: The changes in $\gamma$ ' size (length) and aspect ratio during long term ageing at $650{ }^{\circ} \mathrm{C}$

\begin{tabular}{|l|l|l|l|l|}
\hline & Time $(\mathrm{h})$ & $3000 \mathrm{~h}$ & $10000 \mathrm{~h}$ & $30000 \mathrm{~h}$ \\
\hline as received & Temperature $\left({ }^{\circ} \mathrm{C}\right)$ & 650 & 650 & 650 \\
\hline $18.1 \pm 9.8$ & $\gamma^{\prime}$ particle length & $44.1 \pm 29.8$ & $93.6 \pm 74$ & $155.6 \pm 142$ \\
\hline $0.42 \pm 0.14$ & particle aspect ratio & $\sim 0.4$ & $\sim 0.3$ & $0.24 \pm 0.12$ \\
\hline
\end{tabular}

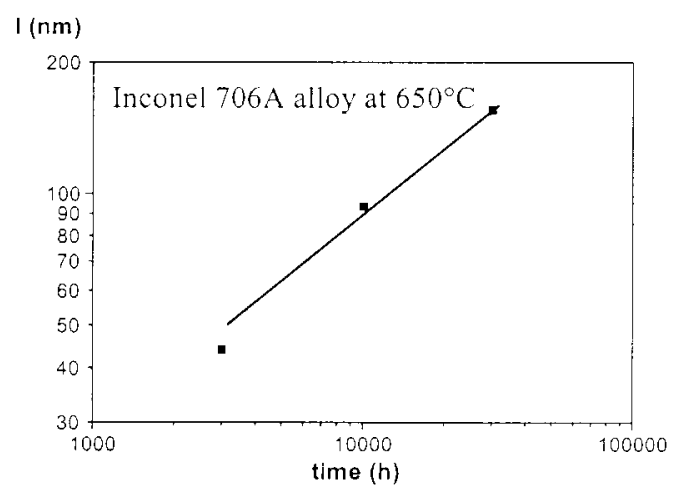

Figure 6: The growth of $\gamma^{\prime \prime}$ precipitates in Inconel $706 \mathrm{~A}$ alloy aged at $650^{\circ} \mathrm{C}$.

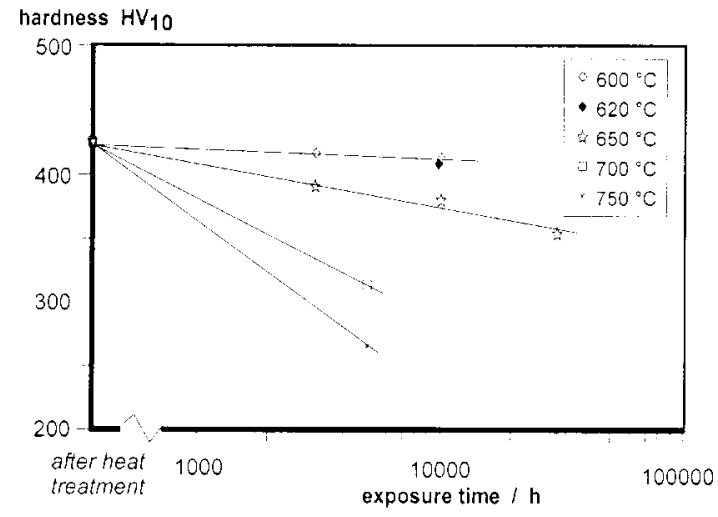

Figure 8: Hardness in dependence on ageing time and temperature

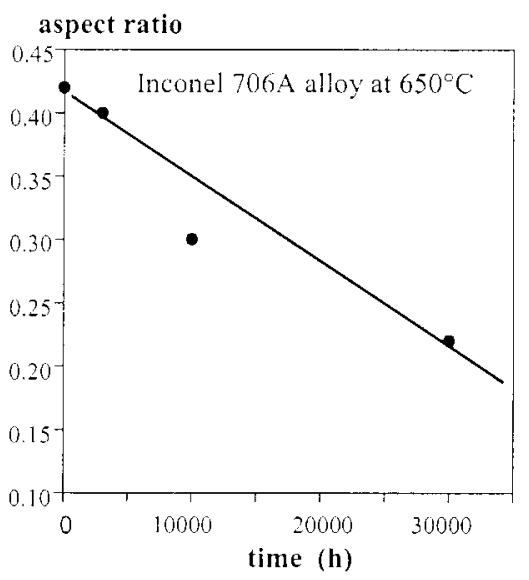

Figure 7: The $\gamma^{\prime \prime}$ particles aspect ratio (morphology) vs. ageing time

The results confirm the preferred growing directions for $\gamma$ ' phase during coarsening. The regression analysis shown in Figure 6 results to the equation $1=0.547 \mathrm{t}^{1 / 2}$ where 1 represents the particle length. This result is different to the growth of $\gamma^{\prime}$-particles in a number of Ni-base alloys following the $d \propto t^{1 / 3}$ rule of the LSW theory [7, 8] and is in agreement with the observation of a mainly planar growth of the $\gamma$ ' particles. This result agrees with the Gibbs-Thompson theory [6] were the driving force for the planary growth is the minimization of the coherency strain. 
At temperatures above $650^{\circ} \mathrm{C}$ and after exposure times of about $3000 \mathrm{~h}$ the $\eta$ phase appeared additionally on grain boundaries and twins. The volume fraction was very small and could not be measured. At $700^{\circ} \mathrm{C}$ and more than $4000 \mathrm{~h} \eta$ phase appeared homogeneously distributed in the grain interior. Figure 8 demonstrates the loss of hardness in dependence on ageing temperature and time. The coarsening of $\gamma^{\prime}$ and $\gamma^{\prime}$ at $600^{\circ} \mathrm{C}$ to $650^{\circ} \mathrm{C}$ caused only a small loss of hardness. At temperatures higher than $650^{\circ} \mathrm{C}$ the transformation to $\eta$ phase occurred and led to a stronger decrease of hardness.

\section{Inconel $706 \mathrm{~B}$}

microstructure after heat treatment. A typical microstructure of Inconel $706 \mathrm{~B}$ is represented by Figure 9. The $\gamma$ ' and $\gamma$ ' particles were homogeneously distributed in the $\gamma$ matrix and exhibited a typical spherical $\left(\gamma^{\prime}\right)$ or prismatic $\left(\gamma^{\prime \prime}\right)$ shape with sizes from 30 to $50 \mathrm{~nm}$.

The $\eta$ phase precipitated at the grain boundaries in a cellular manner (Figure 9) or as a grain boundary film, dependent on the grain boundary orientation.

The platelets grow parallel to the (111) and had one partly coherent interface with the $\{111\}$ plane The orientation relationship between $\gamma$ and $\eta$ phases is given by the relationship $\langle 011\rangle_{\gamma}|<2110\rangle_{\eta}$, $\{111\} \gamma \|\{0001\} \eta$ and was established using electron diffraction technique.

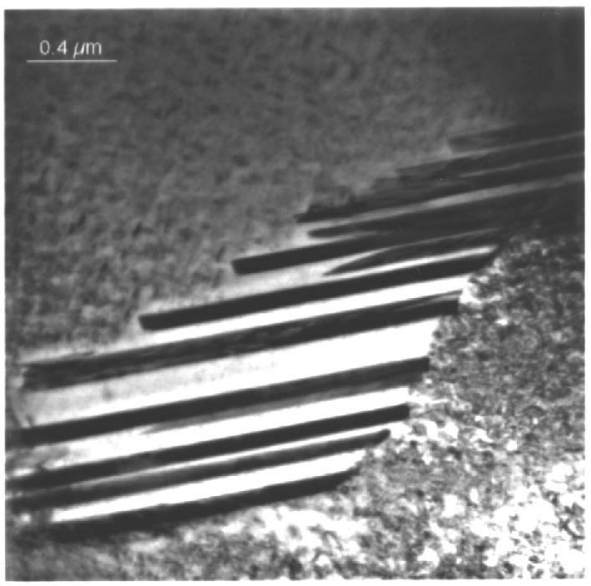

Figure 9: Microstructure of Inconel $706 \mathrm{~B}$ after heat treatment with cellular $\eta$ phase at the grain boundary

Microstructure after ageing. In addition to the coarsening of $\gamma^{\prime}$ and $\gamma$ ' procedures as described in the section Inconel $706 \mathrm{~A}$ for an ageing temperature of $650^{\circ} \mathrm{C}$, the transformation of $\gamma^{\prime}$ into the $\eta$ phase becomes more important for higher ageing temperatures. In Figures 10 and 11 the microstructural features of Inconel $706 \mathrm{~B}$ alloy after ageing at temperatures of 700 and $750{ }^{\circ} \mathrm{C}$ for different ageing times are given.
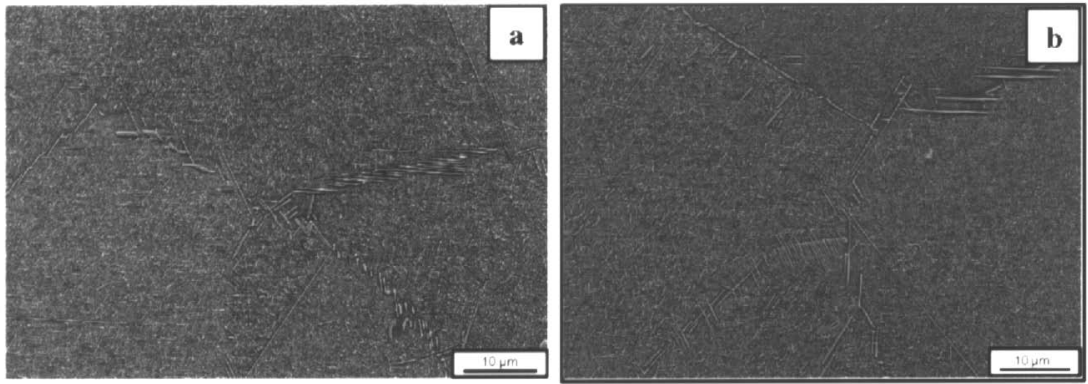

Figure 10: Inconel $706 \mathrm{~B}$ aged at 7()()$) \mathrm{Cor}+27 \mathrm{~h}(\mathrm{a})$ and $1065 \mathrm{~h}(\mathrm{~b})$
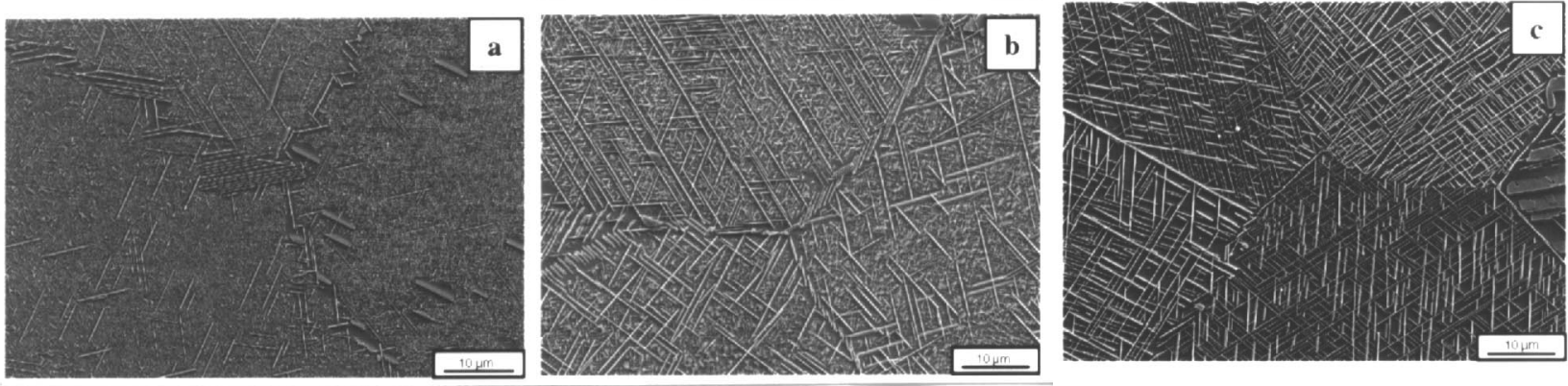

Figure 11: Inconel $706 \mathrm{~B}$ aged at $750^{\circ} \mathrm{C}$ for $297 \mathrm{~h} \mathrm{(a),} 955 \mathrm{~h}(\mathrm{~b})$ and $2330 \mathrm{~h}(\mathrm{c})$. 
The influence of temperature on the transformation to the $\eta$ phase is well documented by the comparison of Figures $10 \mathrm{~b}$ and $11 \mathrm{~b}$ (both specimens were aged with a similar duration). The amount of $\eta$ phase after ageing at $750{ }^{\circ} \mathrm{C}$ was much higher than that after ageing at $700{ }^{\circ} \mathrm{C}$. At $750^{\circ} \mathrm{C}$ after $2330 \mathrm{~h}$, the transformation to the $\eta$ phase was nearly completed. More information was revealed from the TEM images (Figures. 12 and 13). The $\gamma^{\prime}$ and $\gamma$ ' particles were still

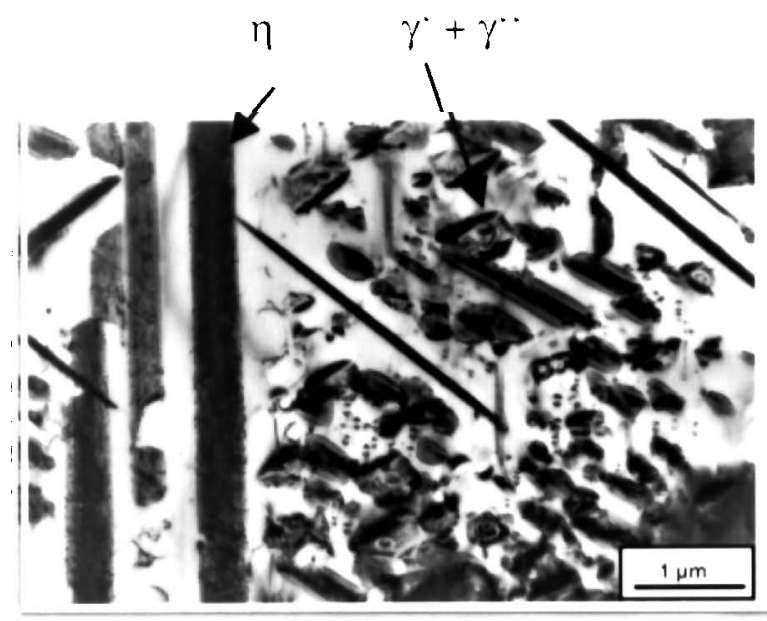

Figure 12: Inconel $706 \mathrm{~B}$ aged at $750^{\circ} \mathrm{C} / 2330 \mathrm{~h}$



Figure 14: Hardness of Inconel $706 \mathrm{~B}$ in dependence on ageing time and temperature

\section{Inconel $706 \mathrm{C}$}

Microstructure after heat treatment. The variant Inconel $706 \mathrm{C}$ with increased $\mathrm{Nb}$ and $\mathrm{C}$ content contained after heat treatment an increased volume fraction of MC carbides than in Inconel $706 \mathrm{~A}$ or $\mathrm{B}$ and $y$ ' particles with a bimodal size distribution. The TEM dark field image of Inconel $706 \mathrm{C}$ shown in Figure 15 demonstrates this fact. The primary $\gamma$ ' reached a length of about $430 \mathrm{~nm}$ and the

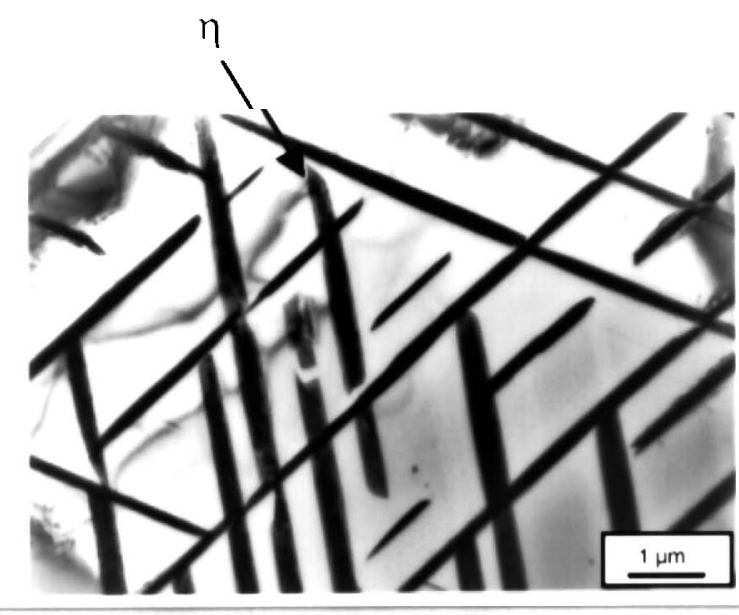

Figure 13: Inconel $706 \mathrm{~B}$ aged at $750^{\circ} \mathrm{C} / 5000 \mathrm{~h}$

visible between the $\eta$ plates after $2330 \mathrm{~h}$ at $750^{\circ} \mathrm{C}$ (Figure 12). In the case of extending the exposure time up to $5000 \mathrm{~h}$, both of the strengthening phases $\gamma$ ' and $\gamma$ ' disappeared and the $\eta$ phase dominated (Figure 13). It can be deduced that time needed to finish the transformation reaction in Inconel $706 \mathrm{~B}$ at $750^{\circ} \mathrm{C}$ is between 3000 and $5000 \mathrm{~h}$. Figure 14 shows the results of hardness measurements. The hardness of Inconel $706 \mathrm{~B}$ after heat treatment is lower than that of Inconel $706 \mathrm{~A}$ and the loss of hardness in dependence on exposure time and temperature indicates the same dependence on $\eta$ phase transformation as with Inconel $706 \mathrm{~A}$.

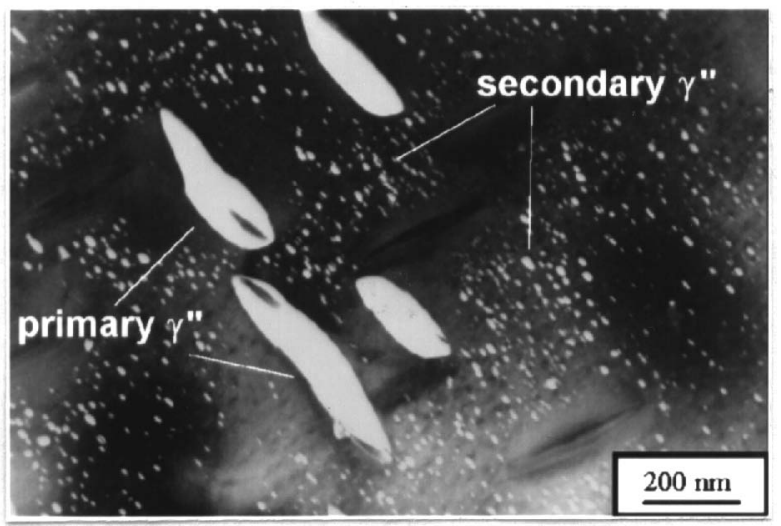

Figure 15: The microstructure of Inconel $706 \mathrm{C}$ after heal treatment type B 
small secondary $\gamma^{\prime \prime}$ precipitates showed a mean size of about $20 \mathrm{~nm}$. This precipitation behavior can be explained by an increase of the solvus temperature of $\gamma$ ' with increasing $\mathrm{Nb}$ content. It was expected that the $\gamma^{\prime \prime}$ precipitation process occurred during the stabilization annealing and the primary $\gamma^{\prime}$ ' grow fast. During the subsequent annealing at $720^{\circ} \mathrm{C}$ and $620^{\circ} \mathrm{C}$ the secondary $\gamma^{\prime}$ ' were precipitated from the supersaturated solution. More detailed investigation of the coarsening kinetic in Inconel $706 \mathrm{C}$ were presented elsewhere [13]. There were no significantly differences detected in respect to the $\eta$ phase formation and the $\gamma^{\prime}, \gamma^{\prime}$ ' coarsening behavior compared to Inconel $706 \mathrm{~B}$.

\section{Waspaloy}

Structure after heat treatment. The microstructure of Waspaloy after heat treatment consists of bimodal distribution of coherent $\gamma^{\prime}$ particles $\mathrm{Ni}_{3}(\mathrm{Ti}, \mathrm{Al})$ with a volume fraction of about 0.25 and $\mathrm{M}_{23} \mathrm{C}_{6}$ precipitates along the grain boundaries with a volume fraction below 0.002 .
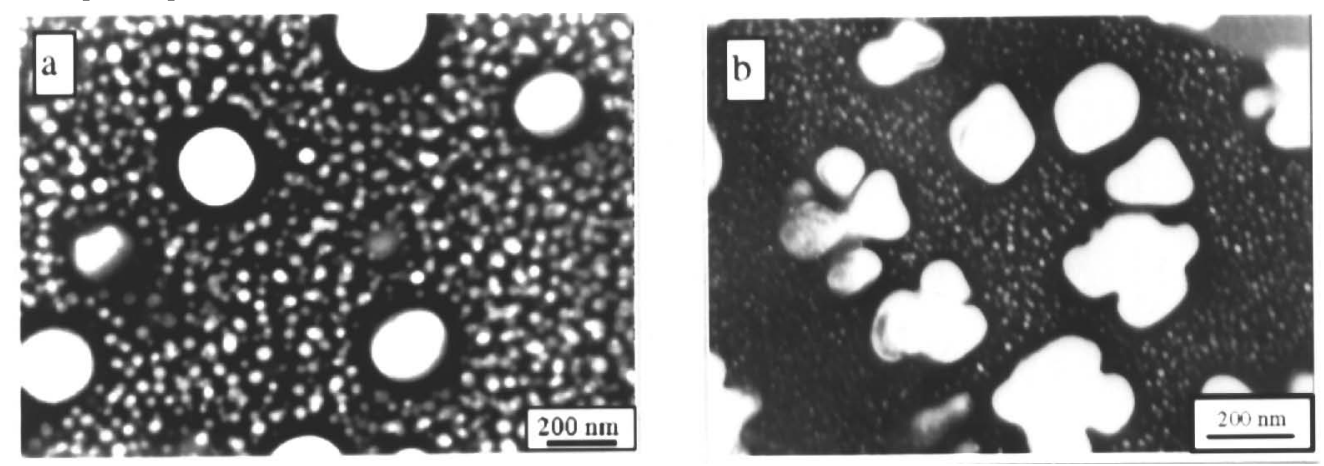

Figure 16: Microstructure of Waspaloy after heat treatment a) closed to surface and b) in the centre of a billet (TEM dark-field image).

Figure 16 shows TEM dark field images of $y^{\prime}$ precipitates in Waspaloy from specimens were took either from a surface near zone (a) or from the center (b) of a billet of $200 \mathrm{~mm}$ in diameter. The large $\gamma^{\prime}$ precipitates, the primary $\gamma^{\prime}$ differ obviously from the fine secondary $\gamma^{\prime}$. The primary $\gamma^{\prime}$ precipitates tended to form spheres in the specimen from the edge and more complex shapes in the billet center. The secondary $\gamma^{\prime}$ particles center specimen were smaller compared to these in the surface specimen. It seems that the complex form of primary $\gamma^{\prime}$ particles is a result of attraction of $\gamma$ ' particles during the cooling down of the heat treatment.
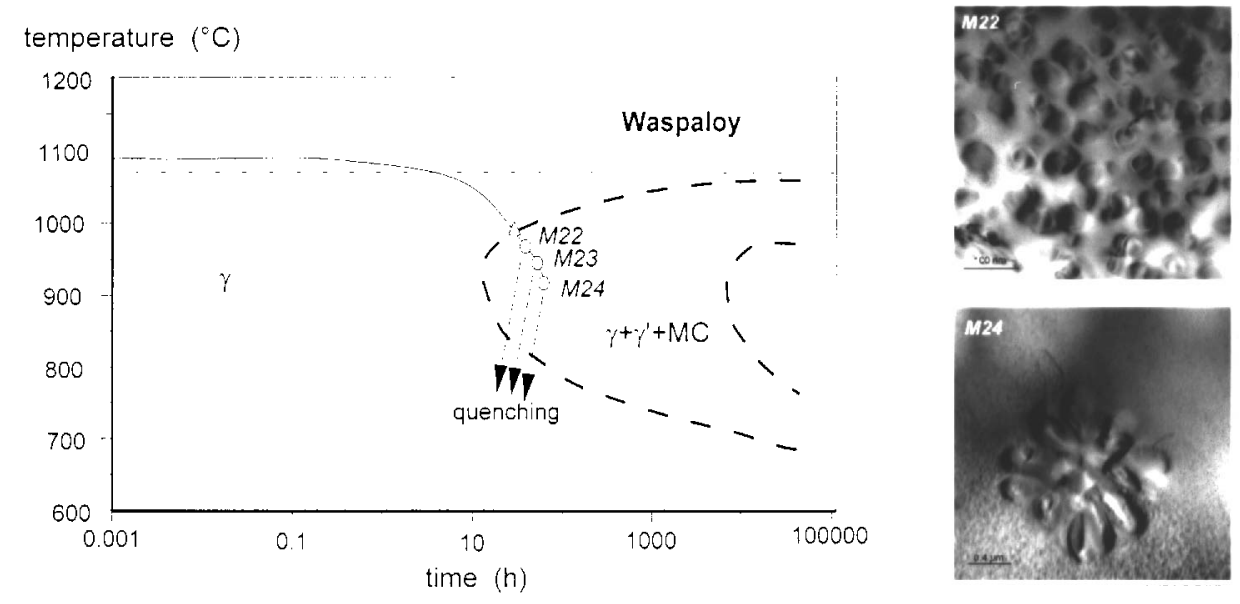

Figure 17: Scheme of cooling down in DTA experiments with Waspaloy. The TEM images show the resulting microstructure at the termination points M22 to M24. 
In order to verify this assumption, the heat treatment steps were simulated in DTA experiments and the cooling rates after the solution annealing were varied. Figure 17 represents a simplified TTT diagram of Waspaloy; the cooling curve of three DTA experiments with an applied cooling rate of $0.1 \mathrm{~K} / \mathrm{min}$ is drawn. The triangle marks the temperature for the $\gamma$ ' precipitation and the circles mark the different terminations of the experiments by water quenching representing different cooling down durations. The structure images show the shape of the resulting $\gamma$ particles.

The images of the experiment M22 terminated $1 \mathrm{~h}$ after the DTA signal (triangle) shows a homogeneous distribution of $\gamma^{\prime}$ particles (about $30-50 \mathrm{~nm}$ ). The image of M24 terminated $7.5 \mathrm{~h}$ after the DTA signal shows an attraction of $\gamma$ ' particles to a local center. The driving force for this attraction might be the removal of the clastically strained matrix lying between two coherent particles if the lattice parameter were different in the precipitates and matrix i.e. the process will depend on the $\gamma^{\prime}$ misfit [12].

Microstructure after ageing. In order to observe the ageing behavior of Waspaloy a set of creep specimens tested at 650,700 and $750^{\circ} \mathrm{C}$ were investigated. After $6700 \mathrm{~h}$ at $650^{\circ} \mathrm{C}$ no significant change in $\gamma^{\prime}$ particle amount and shape has been observed. After exposure at $700{ }^{\circ} \mathrm{C}$ a reduction of secondary $\gamma^{\prime}$ and a coarsening of primary $\gamma^{\prime}$ particles was detected. The volume fraction of secondary $\gamma^{\prime}$ decreased from $4.8 \%$ as received to about $0.1 \%$ after $2500 \mathrm{~h}$ and the volume fraction of primary $\gamma^{\prime}$ increases in the opposite way. After $5000 \mathrm{~h}$ at $750^{\circ} \mathrm{C}$ the small secondary $y^{\prime}$ particles disappeared completely and the dimensions and volume fraction of large primary $\gamma^{\prime}$ particles increased from $13.8 \%$ in as-received conditions to about $22-24 \%$. That means that after heat treatment, the system is not in equilibrium state, not all of possible $\gamma$ ' has been precipitated.

\section{IN 617 alloy}

Microstructure after heat treatment. Inconel 617 is a solid solution hardened Ni-base alloy which is additionally strengthened by $\mathrm{M}(\mathrm{C}, \mathrm{N})$ carbonitrides and by homogeneously distributed $\mathrm{M}_{23} \mathrm{C}_{6}$ carbides with a size of about $60-100 \mathrm{~nm}$ (Figure 18). The distribution of carbides is dependent on the cooling rate after solution annealing and tend slightly to form clusters at lower cooling rates leading to differences in the hardness values within the grains. The influence of carbides mentioned above on the properties of Inconel 617 depends on their morphology. After heat treatment $\mathrm{M}_{23} \mathrm{C}_{6}$ carbides are usually globular and strengthen the matrix and the grain boundaries. The volume fraction of $\mathrm{M}_{23} \mathrm{C}_{6}$ carbides was

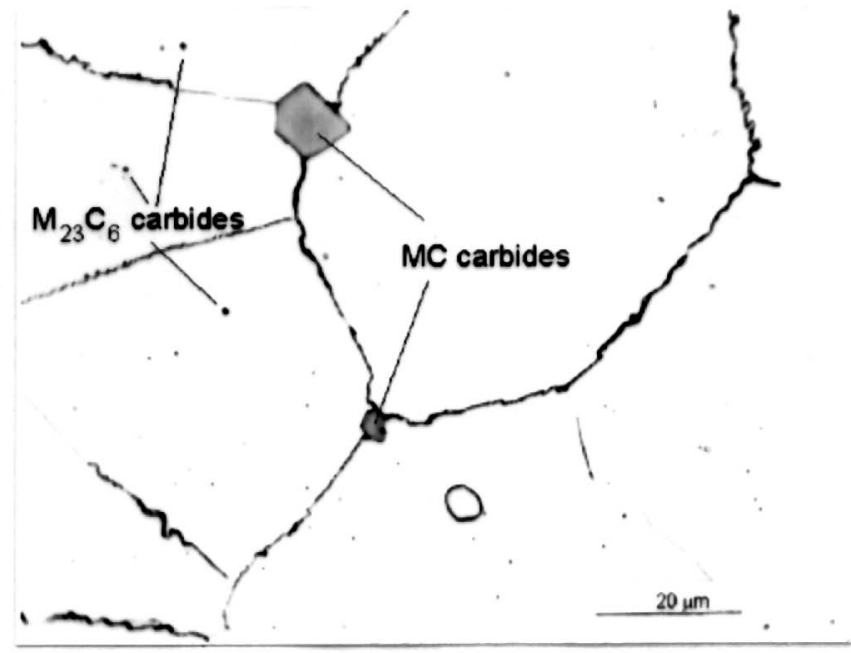

Figure 18: Micrograph of Inconel 617 showing $\mathrm{M}(\mathrm{C}, \mathrm{N})$ carbonitrides and small M23C6 carbides 
volume fraction of homogeneous distributed carbonitrides of the Ti(C,N) type was about 0.004 $\%$. Because of the high Mo content the formation of $\mathrm{M}_{6} \mathrm{C}$ carbides $\left(\mathrm{Mo}_{6} \mathrm{C}\right.$ type) is possible and has been detected (volume fraction about 0.001 ) in TEM analysis.

Microstructure after ageing. During the ageing at temperatures of $700-750{ }^{\circ} \mathrm{C}$ the $\mathrm{M}_{23} \mathrm{C}_{6}$ carbides tended to grow along the grain to form of carbide film at the grain boundaries. Additionally lamellae structures of $\mathrm{M}_{23} \mathrm{C}_{6}$ needles has been found (Figure 19). These kinds of $\mathrm{M}_{23} \mathrm{C}_{6}$ structures has been observed even after an exposure of $100 \mathrm{~h}$ (but in a smaller amount and size). The needle like carbides were clustered to islands and were oriented from the grain boundaries inside the grain interior and parallel to boundary.

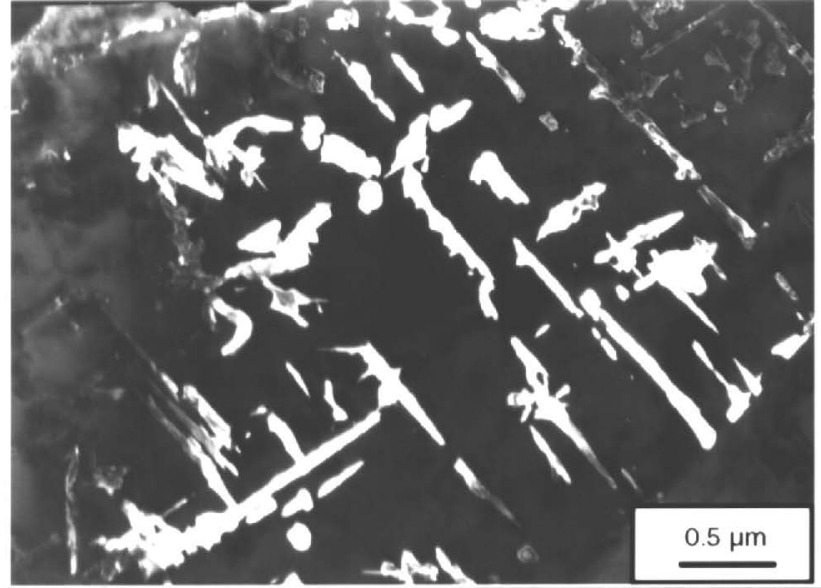

Figure 19: $\mathrm{M}_{23} \mathrm{C}_{6}$ needles formed in Inconel 617 after $5000 \mathrm{~h}$ at $750^{\circ} \mathrm{C}$ (TEM dark field)

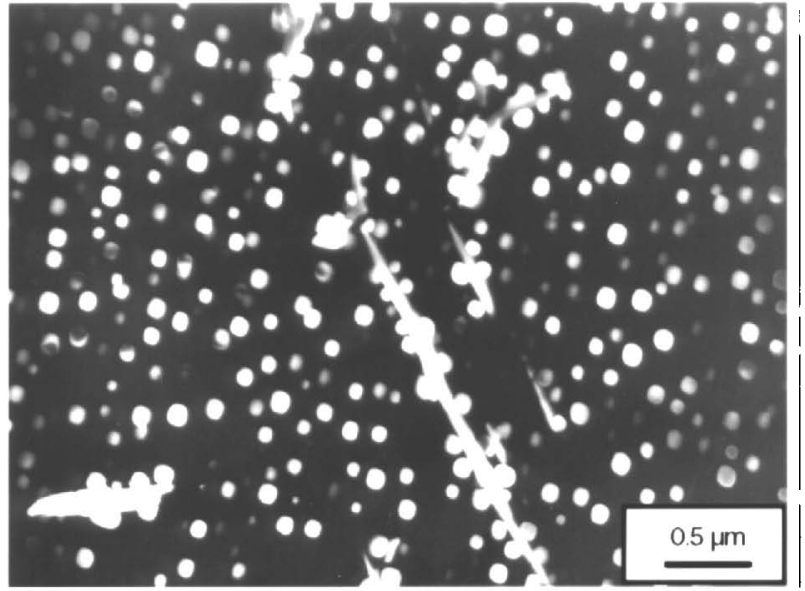

Figure 20: Microstructure of Inconel 617 after $5000 \mathrm{~h}$ at $750^{\circ} \mathrm{C}$ containing $\gamma^{\prime}$ particles and M23C6 needles (TEM dark field)

Two appearances of carbide precipitates at grain boundaries exist: the globular particles and the formation of films along the grain boundaries. It can be deduced that during long term service continuous carbide films will be formed.

An unexpected effect of the ageing of Inconel 617 at 700 to $750{ }^{\circ} \mathrm{C}$ was the precipitation and growth of very homogeneously distributed $\gamma^{\prime}$ particles. The precipitation of $\gamma^{\prime}$ particles of a mean size of about $20 \mathrm{~nm}$ was still observed after $83 \mathrm{~h}$ at $700^{\circ} \mathrm{C}$. After ageing at $750{ }^{\circ} \mathrm{C}$ and $5000 \mathrm{~h} \gamma$ ' particles with a size of about $80-90 \mathrm{~nm}$ and a volume part of about $4 \%$ were detected (Figure 20).

\section{Conclusions}

Three Ni-base wrought alloys, Inconel 706, Waspaloy and Inconel 617, representative for alloys with different hardening mechanisms were investigated in respect to their microstructure and microstructural stability at temperatures from $650{ }^{\circ} \mathrm{C}$ to $750{ }^{\circ} \mathrm{C}$. Inconel 706 is hardened by $\gamma^{\prime}, \gamma^{\prime}$ ' and $\eta$ phases The presence of $\eta$ phase along the grain boundaries can be controlled by the heat treatment. The microstructure is not stable at temperatures above $650{ }^{\circ} \mathrm{C}$ and the microstructural changes are characterized by particle coarsening after medium service life and long term phase transformation into the platelets forming $\eta$ phase. An increase of the $\mathrm{Nb}$ content leads to a bimodal size distribution of $y$ " particles and do not change the amount of $\eta$ phase after heat treatment significantly. 
The alloy Waspaloy exhibits a bimodal size distribution of primary and secondary $\gamma$ ' particles strongly dependent on the cooling rate after solution annealing during the heat treatment. During service life at temperatures above $700^{\circ} \mathrm{C} \gamma$ particles coarsen to a homogeneous microstructure containing with $\gamma^{\prime}$ particles of about $250 \mathrm{~nm}$ diameter.

Inconel 617 is a solution hardened Ni-base alloy exhibiting small $\mathrm{M}_{23} \mathrm{C}_{6}$ carbides after heat treatment. During service life above $700^{\circ} \mathrm{C}$ the carbides tend to form carbide films at the grain boundaries and small needle like precipitates inside the grains. Because of the $\mathrm{Al}$ and Ti content of this alloy $\gamma^{\prime}$ will be precipitated in a homogeneous distribution and a volume fraction of maximum 0.04 .

\section{$\underline{\text { References }}$}

[1] F. Tarcet, H.K.D.H. Bhadeshia and D.J.C. Mac Kay, "Design of new creep-resistant nickel-base superalloys for power plant applications", Key Engineering Materials 171 174 (2000), 529-536.

[2] K.A. Heck, "The Time-Temperature-Transformation Behaviour of Alloy 706", Paper presented on the Conference Superalloys 718, 625, 706 and Various Derivatives, 1994, 393-404.

[3] T. Takahashi et al., "Effects of Grain Boundary Precipitation on Creep Rupture Properties of Alloys 706 and 718 Turbine Disk Forging", Proc. Conf. Superalloys 718, 625, 706 and Various Derivatives, 1994, 557-565.

[4] G.W. Kuhlman, "Microstructure-Mechanical Properties Relationships in Inconel 706 Superalloy" Proc. Conf. Superalloys 718, 625, 706 and Various Derivatives, 1994, 441450.

[5] T.Shibata, et al. "Effect of Stabilizing Treatment on Precipitation Behaviour of Alloy 706”, Proc. Conf. Superalloys 1996, pp. 153-636.

[6] J. Rys and K. Wiencek, Koagulacja faz w stopach, Wydawnictwo Slask, Poland, 1979)

[7] I.M. Lifshitz, V.V. Slyozow "The Kinetics of Precipitation From Supersaturated Solid Solution", Journal Phys. Chem. Solids, 19 (1/2) (1961), 35-50

[8] C. Wagner, "Theorie der Alterung von Niederschlägen durch Umlösen (Ostwald-Reifung)", Zeitschrift für Elektrochemie, 65 (7/8) (1961), 581-591

[9] R. Cozar, A. Pineau, ,Morphology of $\gamma^{\prime}$ and $\gamma$ " Precipitates and Thermal Stability of Inconel 718 Type Alloys", Metallurgical Transactions 4 (1973), 47-

[10] J. P. Collier, "The Effect of Varying Al, Ti, and Nb Content on the Phase Stability of Inconel 718", Metallurgical Transactions A 19A (1988), 1657-1666

[11] C.T. Sims, "A perspective of Niobium in Superalloys", Proceedings of the International Symposium, Niobium'81, held in San Francisco, California, 8-11 November 1981, 1169 1211

[12] R. D. Doherty, "Role of interfaces in kinetics of internal shape changes", Metal Science 16 (1982) $1-13$

[13] J. Wosik et al., "Stereological estimation of microstructural parameters of nickel-base superalloy Waspaloy using TEM methods", Materials Characterization, in press

[14] F. Schubert, H. J. Penkalla, A. Weisbrodt - „PHASCALC*: An improved computer programme for the calculation of phase kinetics, microstructural parameters and microstructural instabilities in Nickel base Superalloys", Paper on the European Conference on Advanced Materials and Processes, Aachen, Germany, 1989,

Acknowledgement

This work is part of the DFG - research programme "Herstellungs- und Lebensdauermodelle für den Einsatz von Nickel-basis Werkstoffen in Dampfturbinen oberhalb $700^{\circ} \mathrm{C}$ ". The financial support of the Deutsche Forschungsgemeinschaft is gratefully acknowledged. 